\section{Twelve dead after earthquake}

\section{Sydney}

THE most disastrous earthquake ever to hit Australia has left 12 dead and A $\$ 1,500$ million worth of damage. On 28 December at 10.27 a.m., the city of Newcastle, $200 \mathrm{~km}$ north of Sydney, experienced an earthquake measuring 5.5 on the Richter scale and lasting, according to amateur measurements, 29 seconds. The epicentre lay almost directly below the southern end of the central business district, $5 \mathrm{~km}$ from the centre of the city. But because the nearest scismometers are $180 \mathrm{~km}$ away, scientists have little to say about the geophysical nature of the seismological event.

Although earthquakes are rare in southeastern Australia, there is a recognized zone of activity extending from Victoria through most of the eastern parts of New South Wales (NSW). Newcastle lies on the northern border of the risk area identified by the Bureau of Mineral Resources (BMR). According to David Denham of BMR, south-east Australia can expect an earthquake of magnitude earthquake in the region occurred in Wonnangatta in Victoria in 1982, and was of magnitude 5.4 .

Most of the basement rocks in southeastern Australia are compressed metamorphosed sediments, granites and volcanics formed more than 400 million years ago. This is overlain by the 260 million-year-old Permian rock of the Sydney basin. 5 or greater every eight years. The last
Earthquakes usually occur deep in the basement, not in the overlying Sydney basin, and because the region lies within a single continental plate, earthquakes are not directly the result of motion at the boundary between plates. Nevertheless, says Denham, it is the build-up of pressure at the plate margins that is the ultimate

\section{IMAGE UNAVAILABLE FOR COPYRIGHT REASONS}

\section{Damaged cars in Newcastle.}

cause of intraplate earthquakes. Confirmation of this explanation of the Newcastle earthquake awaits the collation of data from many seismic stations. Intraplate earthquakes, Denham adds, rarely exceed a Richter magnitude of 7; the recent San Francisco earthquake, registering 7.1, was at a well-known plate boundary.

In the past 25 years, there have been only six earthquakes in Australia that ruptured the surface. The intensity of the LOMA PRIETA EARTHQUAKE

\section{Israelis and Soviets talk science}

\section{Jerusalem}

IN only the second ministerial visit to Moscow since the Soviet Union severed relations with Israel in 1967, Israeli science and technology minister Ezer Weizman is this week discussing with Guri Marchuk, president of the Soviet Academy of Sciences, plans for scientific cooperation between the two countries. Weizman and Marchuk are expected to sign an agreement today, 11 January, with particular emphasis on space exploration.

Weizman's trip was almost cancelled last week when Prime Minister Yitzhak Shamir sacked him from the government for allegedly meeting, illegally, with members of the Palestine Liberation Organization. $\mathrm{He}$ was quickly reinstated, but is still banned from the decision-making inner cabinet.

In Jerusalem last week, meanwhile, Israel and Italy formally renewed their commitment to scientific cooperation. Officials of both countries' national councils for research and development agreed that as 1992 approaches this agreement will help Israel's chances of participating in European research projects. Lisa Perlman

Newcastle earthquake overwhelmed seismic stations in most of southeastern Australia, which were therefore unable to record the event with any accuracy. It was initially suggested that heavy mining in the area may have increased the damage caused by the earthquake, and although this idea was later discounted, disruptions to the ground structure from the mines may have caused the damage to be distributed unevenly.

The depth of the earthquake is not exactly known, but a single aftershock, felt 25 hours later and registering a magnitude of 1.5 , occurred at a depth of 13 $\mathrm{km}$. According to Gary Gibson, director of the Seismology Research Centre at the Phillip Institute of Technology in Melbourne, although the earthquake was deep, the local geography amplified the damage. He said that the greatest disturbance occurred in areas of alluvial fill and sediments, which amplified the seismic waves just as landfills did in the Marina district of San Francisco.

Although Newcastle has had two earthquakes of magnitude 5 or greater in the past (of 5.3 in 1868, and of 5.0 in 1925) the city is considered, by the Standards Association of Australia (SAA), to lie in a seismic zone 1 , the lowest classification. But this zoning dates back to 1979 , at which time the 1868 and 1925 earthquakes had not been added to the historical record. The classification is empirically based, and in fact an SAA committee met in December, a few weeks before the recent earthquake, to reconsider the tenyear-old zoning.

Tania Ewing 